\title{
Hyperuricemia and chronic kidney disease: to treat or not to treat
}

\author{
Hiperuricemia e doença renal crônica: tratar ou não tratar
}

\section{Authors}

Federica Piani ${ }^{1,2}$ (D)

Fumihiko Sasai ${ }^{1 *}$ iD

Petter Bjornstad ${ }^{1}$ iD

Claudio Borghi ${ }^{2}$ iD

Ashio Yoshimura $^{3}$ iD

Laura G. Sanchez-Lozada' ${ }^{\text {iD }}$

Carlos Roncal-Jimenez ${ }^{1}$ iD

Gabriela E. Garcia ${ }^{1}$ iD

Ana Andres Hernando ${ }^{1}$ iD

Gabriel Cara Fuentes ${ }^{1}$ iD

Bernardo Rodriguez-Iturbe ${ }^{4}$ iD

Miguel A Lanaspa' ${ }^{1}$ iD

Richard J Johnson ${ }^{1,5}$ iD

'University of Colorado School of Medicine, Division of Renal Diseases and Hypertension, Department of Medicine, Aurora, CO, USA.

${ }^{2}$ University of Bologna,

Department of Medical and

Surgical Sciences, Bologna, Italy.

${ }^{3}$ Shin-Yokohama Daiichi Hospital,

Yokohama, Kanagawa, Japan.

${ }^{4}$ Hospital Universitario de

Maracaibo, Instituto de

Investigaciones Científicas, Ivic-

Zulia, Maracaibo, Venezuela.

${ }^{5}$ Rocky Mountain VA Medical

Center, Aurora, CO, USA.

Submitted on: 12/16/2020

Approved on: 12/28/2020.

\section{Correspondence to:}

Federica Piani.

E-mail:federica.piani@cuanschutz.edu

DOI: https://doi.org/10.1590/21758239-JBN-2020-U002

\section{Abstract}

Hyperuricemia is common in chronic kidney disease (CKD) and may be present in $50 \%$ of patients presenting for dialysis. Hyperuricemia can be secondary to impaired glomerular filtration rate (GFR) that occurs in CKD. However, hyperuricemia can also precede the development of kidney disease and predict incident CKD. Experimental studies of hyperuricemic models have found that both soluble and crystalline uric acid can cause significant kidney damage, characterized by ischemia, tubulointerstitial fibrosis, and inflammation. However, most Mendelian randomization studies failed to demonstrate a causal relationship between uric acid and CKD, and clinical trials have had variable results. Here we suggest potential explanations for the negative clinical and genetic findings, including the role of crystalline uric acid, intracellular uric acid, and xanthine oxidase activity in uric acid-mediated kidney injury. We propose future clinical trials as well as an algorithm for treatment of hyperuricemia in patients with CKD.

Keywords: Hyperuricemia; Uric Acid; Acute Kidney Injury; Renal Insufficiency, Chronic; Allopurinol; Cardiovascular Disease.

\section{Resumo}

A hiperuricemia é comum na doença renal crônica (DRC) e pode estar presente em até $50 \%$ dos pacientes que se apresentam para diálise. A hiperuricemia pode ser secundária ao comprometimento da taxa de filtração glomerular (TFG) que ocorre na DRC. No entanto, ela também pode preceder o desenvolvimento da doença renal e mesmo prever uma DRC incidente. Estudos experimentais de modelos hiperuricêmicos descobriram que tanto o ácido úrico solúvel quanto o cristalino podem causar danos renais significativos, caracterizados por isquemia, fibrose tubulointersticial e inflamação. Entretanto, a maioria dos estudos de randomização Mendeliana falhou em demonstrar uma relação causal entre o ácido úrico e a DRC, e os ensaios clínicos têm apresentado resultados variáveis. Aqui sugerimos explicações potenciais para os achados clínicos e genéticos negativos, incluindo o papel do ácido úrico cristalino, do ácido úrico intracelular e da atividade da xantina oxidase na lesão renal mediada por ácido úrico. Propomos ensaios clínicos futuros, bem como um algoritmo para o tratamento de hiperuricemia em pacientes com DRC.

Descritores: Hiperuricemia; Ácido Úrico; Lesão Renal Aguda; Insuficiência Renal Crônica; Alopurinol; Doenças Cardiovasculares.

\section{INTRODUCTION}

The prevalence of chronic kidney disease (CKD) and hyperuricemia is increasing worldwide ${ }^{1}$. CKD is commonly associated with gout, and the association dates back to the mid-nineteenth century ${ }^{2,3}$. Numerous epidemiological studies have consistently shown that hyperuricemia independently predicts new onset $\mathrm{CKD}^{4-6}$. In addition, hyperuricemia frequently associates with other risk factors for
CKD, such as hypertension and metabolic syndrome ${ }^{1}$. However, most Mendelian randomization studies have failed to find a causal relationship ${ }^{7}$. Clinical trials have also provided inconsistent data; while earlier trials have generally shown benefit, two recent clinical trials found no effects of lowering serum uric acid in participants with type 1 diabetes with CKD or in patients with non-diabetic CKD (Table 1). Furthermore, it remains debated whether 
asymptomatic hyperuricemia in the absence of gout confers similar risk for CKD as those with gout ${ }^{4}$. Here we discuss the controversy of the role of hyperuricemia in $\mathrm{CKD}$, and critically appraise the therapeutic role of lowering serum uric acid in patients with CKD.

\section{PATHOGENESIS OF HYPERURICEMIA IN CKD}

Although uric acid concentrations are tightly regulated in most species, humans lost this regulatory capacity due to a mutational loss in uricase that degrades uric acid to 5-hydroxyisourate and subsequently allantoin ${ }^{8}$. A consequence is that serum uric acid can be increased by dietary intake of purine rich foods, fructose, and alcohol. In turn, regulation of uric acid concentrations is primarily via excretion by the kidney (two-thirds of total elimination) and gut (one-third) ${ }^{9}$. In addition, a small amount of uric acid is metabolized by oxidants to allantoin, triuret or 6 -aminouracil ${ }^{10}$. In the kidney, uric acid is freely filtered, with a net $90 \%$ reabsorbed in the proximal tubule by different transporters (e.g. urate transporter 1 (URAT1), and organic anion transporter 4 (OAT4)), and with approximately $10 \%$ excreted $^{11}$. As kidney function declines, uric acid is retained $^{12}$. However, it has been demonstrated that renal impairment is accompanied by a significant compensatory increase in the fractional excretion of uric acid (FeUA) and in the excretion of uric acid per volume of glomerular filtration ${ }^{12}$. Furthermore, extra-renal uric acid excretion also increases as a compensatory response to reduced kidney excretion of uric acid $^{13}$. Thus, while impaired kidney function will increase serum uric acid levels, its contribution is less than the effects of impaired kidney function on, for example, blood urea nitrogen and creatinine.

While hyperuricemia can result from impaired kidney function, numerous studies have reported that hyperuricemia commonly precedes the development of $\mathrm{CKD}^{14-16}$. This may occur in part because conditions such as obesity, metabolic syndrome, and hypertension are risk factors for CKD and are also commonly associated with hyperuricemia. Proposed mechanisms for the hyperuricemia in these conditions include insulin-dependent reduction in FeUA, hypercholesterolemia-mediated increase in xanthine oxidase (XO) activity, and hypertensioninduced afferent arteriolar vasoconstriction with renal retention of uric acid ${ }^{17-19}$.

A genetic predisposition to hyperuricemia and kidney injury has also been shown. In fact, genetic polymorphisms in the regulation of serum uric acid levels have been associated with estimated glomerular filtration rate $(\mathrm{eGFR})^{20}$. Additionally, some medications commonly administered to patients with CKD, such as diuretics and immunosuppressants, may also raise serum uric acid concentrations ${ }^{21}$.

\section{EPIDEMIOLOgY OF THE ASSOCIATION}

Hyperuricemia is a strong independent risk factor for incident $\mathrm{CKD}^{14-16,22-28}$. The relationship of serum uric acid with incident CKD is not linear, but risk shows a rapid increase as serum uric acid concentrations reach $7 \mathrm{mg} / \mathrm{dL}$ or more ${ }^{29,30}$. In contrast, once patients develop CKD, serum uric acid is more variable, with some studies suggesting it is an independent predictor for worsening of $\mathrm{CKD}^{16,31,32}$ whereas others studies suggest it is not ${ }^{6,33}$. There are also some studies from Japan that suggest a low uric acid may magnify risk for CKD, but this may be due the relatively higher frequency of mutations in the transporter URAT-1 that is associated with severe uricosuria and recurrent acute kidney injury $(\mathrm{AKI})^{34,35}$.

Some genetic studies also suggest that hyperuricemia may confer risk for $\mathrm{CKD}$, especially in Mexican American, Native American, and Italian populations ${ }^{20,36,37}$. However, a recent large Mendelian randomization study did not find any association between serum uric acid, eGFR, and $\mathrm{CKD}^{7}$.

These controversial results could be a consequence of selection biases due to the heterogeneity of the hyperuricemic population. For example, it may make a difference whether the hyperuricemia is primary (e.g., dietary or from increased synthesis) or secondary (e.g., due to passive retention from attenuated renal excretion due to an impaired eGFR). Another variable could be the level of hyperuricemia, for, as mentioned, the relationship between serum uric acid levels and the development of CKD is not linear but increases exponentially for values of serum uric acid $>7 \mathrm{mg} / \mathrm{dL}$ and especially $>9 \mathrm{mg} / \mathrm{dL}^{16,29,32,38}$. It is also plausible that it may relate to whether there is crystal deposition in the kidney, which might be expected to be higher in patients with gout, although people with asymptomatic hyperuricemia may also have silent crystal deposition in joints and other organs ${ }^{39,40}$. Indeed, gout has been associated with a higher risk of advanced CKD compared to asymptomatic hyperuricemia ${ }^{41,42}$. It is thus evident how prior studies are not easily generalizable, as distinct subgroups of people with hyperuricemia may show a different risk of CKD. 
TABle 1 Clinical studies on URIC ACID lOWERING DRUgs IN PATIENTS WITH CKD

\begin{tabular}{|c|c|c|c|c|c|}
\hline Study & $\mathbf{n}$ & Study population & Drug & FU & Result \\
\hline Siu $2006^{67}$ & 54 & $\begin{array}{c}\text { Patients with } \\
\text { hyperuricemia and } \\
\text { CKD }\end{array}$ & Allopurinol & $12 \mathrm{~m}$ & $\begin{array}{l}\text { Allopurinol helps preserve kidney } \\
\text { function during } 12 \text { months of therapy } \\
\text { compared with controls }\end{array}$ \\
\hline $\begin{array}{l}\text { Goicoechea } \\
2010^{68}\end{array}$ & 113 & Patients with CKD & $\begin{array}{l}\text { Allopurinol } \\
\text { vs Controls }\end{array}$ & $24 m$ & $\begin{array}{l}\text { Allopurinol decreased C-reactive } \\
\text { protein and delayed the progression } \\
\text { of renal impairment in patients with } \\
\text { chronic kidney disease }\end{array}$ \\
\hline Hosoya $2014^{69}$ & 123 & $\begin{array}{l}\text { Patients aged } \\
20-75 \text { years, with } \\
\text { hyperuricemia and } \\
\text { CKD stages } 2-3\end{array}$ & $\begin{array}{l}\text { Topiroxostat } \\
\text { vs Placebo }\end{array}$ & $5.5 \mathrm{~m}$ & $\begin{array}{l}\text { Changes in eGFR were not } \\
\text { significantly different between } \\
\text { topiroxostat and placebo groups }\end{array}$ \\
\hline Sircar $2015^{70}$ & 93 & $\begin{array}{c}\text { Patients with CKD } \\
\text { stages 3-4 }\end{array}$ & $\begin{array}{l}\text { Febuxostat vs } \\
\text { Placebo }\end{array}$ & $6 m$ & $\begin{array}{l}\text { Febuxostat significantly decrease the } \\
\text { decline in eGFR compared to placebo }\end{array}$ \\
\hline $\begin{array}{l}\text { Xuemei } \\
\text { Liu } 2018^{71}\end{array}$ & 832 & $\begin{array}{l}\text { Meta-analysis: } 12 \\
\text { RCTs }\end{array}$ & $\begin{array}{l}\text { Allopurinol or } \\
\text { Febuxostat }\end{array}$ & $4-24 m$ & $\begin{array}{l}\text { The risk of worsening of kidney } \\
\text { function or ESRD or death was } \\
\text { significantly decreased in the } \\
\text { treatment group compared to the } \\
\text { control group }\end{array}$ \\
\hline Kimura $2018^{72}$ & 443 & $\begin{array}{l}\text { Japanese patients } \\
\text { with stage } 3 \text { CKD } \\
\text { and asymptomatic } \\
\text { hyperuricemia }\end{array}$ & $\begin{array}{l}\text { Febuxostat vs } \\
\text { placebo }\end{array}$ & $27 m$ & $\begin{array}{l}\text { Febuxostat did not mitigate the } \\
\text { decline in kidney function }\end{array}$ \\
\hline Lee $2019^{73}$ & 141 & $\begin{array}{l}\text { Patients with } \\
\text { hyperuricemia and } \\
\text { CKD stage } 3\end{array}$ & $\begin{array}{l}\text { Febuxostat vs } \\
\text { Allopurinol }\end{array}$ & $5 y$ & $\begin{array}{l}\text { Febuxostat reduced serum uric acid } \\
\text { level and delayed CKD progression } \\
\text { more effectively than allopurinol }\end{array}$ \\
\hline Badve $2020^{60}$ & 363 & $\begin{array}{l}\text { Patients with stage } \\
\text { 3-4 CKD and no } \\
\text { history of gout } \\
\text { who had a urinary } \\
\text { albumin:creatinine } \\
\text { ratio } \geq 265 \text { or an eGFR } \\
\text { decrease of at least } \\
3.0 \mathrm{~mL} / \mathrm{min} / 1.73 \mathrm{~m} 2 \\
\text { in the preceding year }\end{array}$ & $\begin{array}{l}\text { Allopurinol vs } \\
\text { Placebo }\end{array}$ & $26 m$ & $\begin{array}{c}\text { Allopurinol did not significantly slow } \\
\text { the decline in eGFR compared with } \\
\text { placebo }\end{array}$ \\
\hline Doria $2020^{59}$ & 530 & $\begin{array}{c}\text { Patients with } \\
\text { type } 1 \text { diabetes, } \\
\text { SUA>4.5mg/dL, } \\
\text { and eGFR40 99mL/ } \\
\text { min/1.73 m2 }\end{array}$ & $\begin{array}{l}\text { Allopurinol vs } \\
\text { Placebo }\end{array}$ & $38 m$ & $\begin{array}{c}\text { No significant differences in CKD } \\
\text { progression between allopurinol and } \\
\text { placebo were observed }\end{array}$ \\
\hline Hsu $2020^{74}$ & 6057 & $\begin{array}{l}\text { Patients with stage } \\
5 \text { CKD prescribed } \\
\text { either febuxostat or } \\
\quad \text { allopurinol }\end{array}$ & $\begin{array}{l}\text { Febuxostat vs } \\
\text { Allopurinol }\end{array}$ & $4 y$ & $\begin{array}{c}\text { Febuxostat decreased the rate of } \\
\text { progression to dialysis }\end{array}$ \\
\hline Sezai $2020^{75}$ & 55 & $\begin{array}{l}\text { Patients with CKD } \\
\text { stage } 3-4\end{array}$ & $\begin{array}{l}\text { Febuxostat vs } \\
\text { Topiroxostat }\end{array}$ & $1 \mathrm{y}$ & $\begin{array}{l}\text { Febuxostat had stronger } \\
\text { renoprotective and antioxidant } \\
\text { effects than topiroxostat }\end{array}$ \\
\hline
\end{tabular}

List of abbreviations: CKD, chronic kidney disease; eGFR, estimated glomerular filtration rate; FU, follow-up.

There is also some evidence that the biologic effects of uric acid to cause kidney disease may be mediated more by the intracellular effects of uric acid as opposed to serum uric acid ${ }^{43,44}$. Intracellular levels might be higher in the setting where synthesis is stimulated, such as may be observed with high xanthine oxidoreductase (XO) activity. Plasma $\mathrm{XO}$ activity is associated with CKD progression and cardiovascular outcomes, independently of serum uric $\operatorname{acid}^{45,46}$. This could potentially explain why serum uric acid may not predict CKD by Mendelian randomization studies, as the polymorphisms in urate transporters 
that predict hyperuricemia may have different effects on intracellular uric acid concentrations ${ }^{47}$.

\section{DOES URIC ACID CAUSE KIDNEY INJURY?}

Hyperuricemia is thought to cause kidney injury by both crystal-dependent and crystal-independent mechanisms ${ }^{48}$ (Figure 1).

The crystal-dependent pathway involves the deposition of monosodium urate crystals in the tubules or interstitium in the kidney in the outer medulla that leads to chronic inflammation and tubular damage ${ }^{48}$. Recently it has been suggested that this can be diagnosed by renal ultrasound showing a "hyperechoic" outer medulla, and that it may be present in one-third of patients with gout where it correlates with kidney function ${ }^{49}$. Interestingly, the presence of this microcrystalline nephropathy was not associated with urinary evidence for urate crystalluria, underlying the independence of the two pathophysiologic mechanisms ${ }^{49}$. Of note, urate crystals have also been discovered to deposit in both the aorta and coronary arteries, where they may have a role in plaque formation and vascular calcification ${ }^{40}$.
As such, the crystal-dependent pathway may also be a mechanism by which uric acid may be involved in the pathogenesis of atherosclerosis and heart disease.

Soluble, intracellular uric acid may also cause CKD via a crystal-independent process. This may occur by either uptake of uric acid from the circulation or by endogenous generation such as from dietary fructose $\mathrm{e}^{50}$. The mechanism involves elevations in both systemic and intraglomerular pressure coupled with afferent arteriolar vasoconstriction with impaired renal blood flow that is mediated by activation of the renin angiotensin aldosterone (RAAS) system, a reduction in endothelial nitric oxide bioavailability and the induction of oxidative stress ${ }^{51,52}$. There is also vascular smooth muscle cell proliferation that leads to an arteriolopathy that impairs autoregulation, and also effects on tubules that include epithelialmesenchymal changes and inflammatory changes ${ }^{53-55}$. Indeed, ischemia is one of the main pathology findings in both human and animal kidney of subjects affected by hyperuricemia and gout ${ }^{56}$. Of note, most of the animal studies on hyperuricemia have used the oxonic acid-induced hyperuricemic rat model ${ }^{57}$.

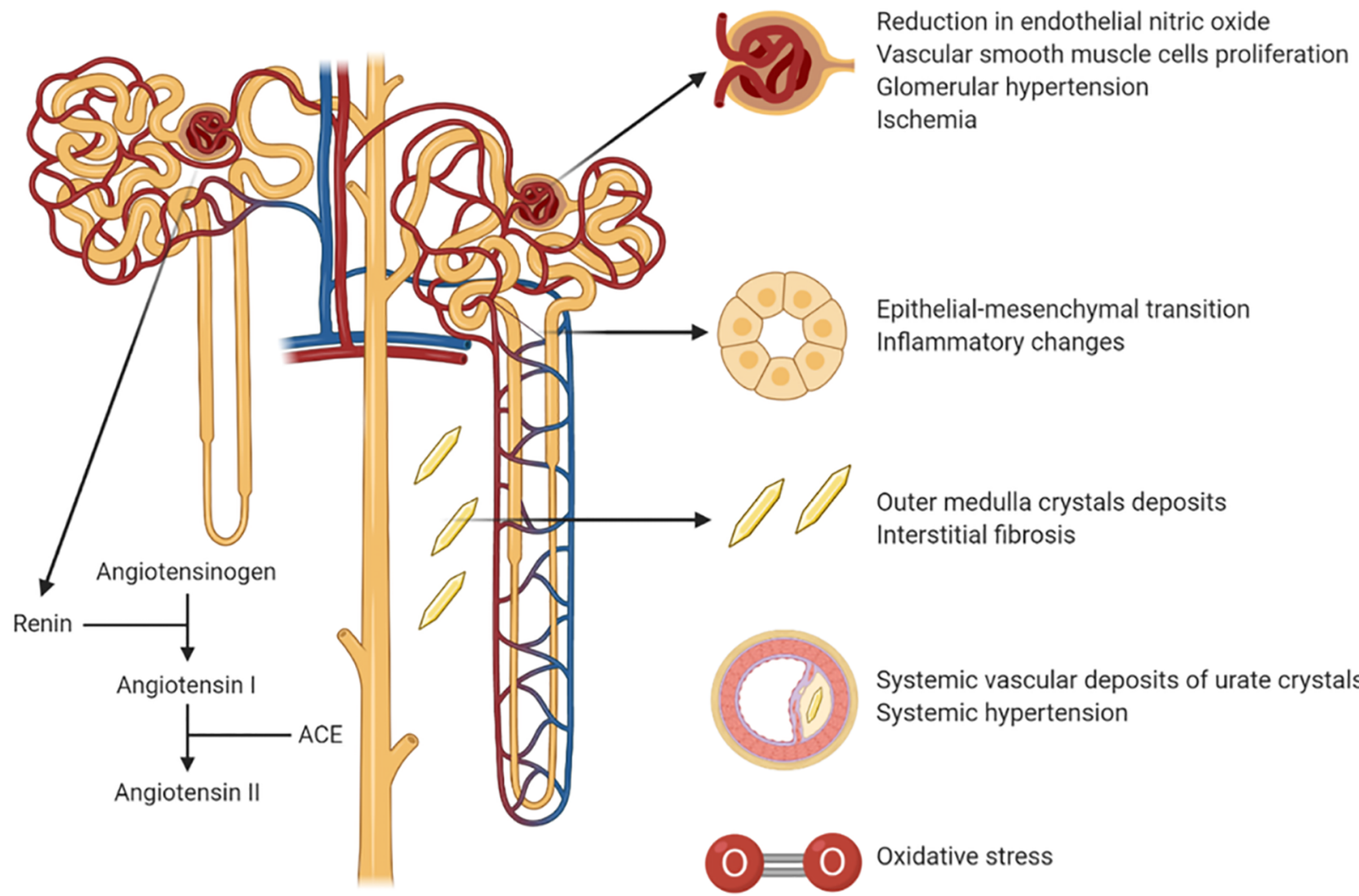

Figure 1. Mechanisms of uric acid-induced kidney injury. 
CLINICAL TRIALS OF URIC ACID IN CHRONIC KIDNEY DISEASE

Experimental trials of uric acid lowering drugs in CKD have been mixed (Table 1). One analysis suggested that a primary reason for the mixed results was that some trials were too short or underpowered to show meaningful progression in the control groups, thus making it difficult to show a benefit in the treatment group. In essence, if the control group does not demonstrate worsening of the underlying disease, it is challenging for any treatment to demonstrate protection. Indeed, studies showing meaningful progression (defined as $\geq 4 \mathrm{~mL} / \mathrm{min} / 1.73 \mathrm{~m}^{2}$ decrease in the control group over the time course of the study) were associated with a benefit of urate-lowering therapy. This analysis argued for urate-lowering therapy in participants with hyperuricemia and $\mathrm{CKD}^{58}$.

More recently, two large clinical trials, the Preventing Early Renal Loss in Diabetes (PERL) and the Controlled Trial of Slowing of Kidney Disease Progression from the Inhibition of Xanthine Oxidase (CKD-FIX) studies, were published in which significant progression did occur in the control groups but for which no benefit in treatment of uric acid levels were noted ${ }^{59,60}$. The PERL was well designed but the participants who had type 1 diabetes did not have gout, and the majority had normal serum uric acid concentrations. The CKD-FIX also did not enroll participants with gout and included subjects irrespective of their serum uric acid concentration. Both groups also had dropout rates greater than 15 percent which were included in the analysis as they were intention-to-treat studies. Hence, neither study targeted the population at risk, that being participants with hyperuricemia with or without gout, and thus conclusions on treating hyperuricemia in CKD are still unclear.

\section{TREATMENT RECOMMENDATIONS}

Before any recommendations are provided, it is important to discuss the potential toxicities of the various treatments. Allopurinol is a xanthine oxidase inhibitor that is usually well tolerated, but it can be associated with a severe hypersensitivity syndrome mimicking a Stevens Johnson syndrome in individuals carrying the HLA B58 allele ${ }^{61}$. This is especially common in the Asian population. The other common xanthine oxidase inhibitor, febuxostat, does not appear to have this side effect but was associated with increased all-cause and cardiovascular mortality compared to allopurinol in the CARES trial (62), although another recently published trial did not observe any difference between allopurinol and febuxostat on cardiovascular outcomes ${ }^{63}$. In the CARES trial, most of the cardiovascular events occurred after the febuxostat was stopped ${ }^{64}$. Stopping xanthine oxidase inhibitors has been associated with worsening of kidney function in patients with CKD, but only in those who are not on RAAS blockers ${ }^{65}$. Since treatment of xanthine oxidase inhibitors is known to block the RAAS ${ }^{66}$, it is possible that stopping xanthine oxidase inhibitors could cause a rebound activation of the RAAS.

Other uric acid lowering agents include uricosurics, but these are not recommended in patients with CKD as acute rises in urine uric acid may cause transient worsening of kidney function. However, this may be mitigated by combining a uricosuric with a xanthine oxidase inhibitor. Finally, uric acid can also be lowered by recombinant uricases such as pegloticase and rasburicase. However, some individuals may develop antibodies to these agents that can limit their eventual effectiveness.

Clearly, more clinical trials are needed. However, based on the fact that marked hyperuricemia appears to carry significant risk for kidney disease progression that could involve both crystal-dependent and -independent mechanisms, we suggest that treatment should be considered for individuals with serum uric acid concentrations of $8 \mathrm{mg} / \mathrm{dL}$ or higher and evidence of progression of their kidney disease, as well as patients with a history of gout irrespective of their underlying serum uric acid concentration. In Table 1 we summarized the main clinical studies on uric acid lowering drugs in patients with CKD. We would recommend assessing if patients are on a RAAS inhibitor before initiating allopurinol (beginning with low doses of $50 \mathrm{mg}$ daily with slow titling to a maximum of $300 \mathrm{mg} /$ daily). All patients are told to stop allopurinol if they develop a rash, and those of Asian ancestry should consider HLA typing prior to drug initiation. Alternatives to allopurinol could include febuxostat or combination uricosuricxanthine oxidase combinations. Pegloticase can also be used for those with severe and refractory gout.

In summary, hyperuricemia is a risk factor for CKD, and there is strong evidence that it can cause kidney 
disease by either crystal-dependent or -independent mechanisms. Nevertheless, trials examining the effects of uric acid lowering interventions in CKD have been inconsistent, although this be ascribed to the trials not targeting the participants most likely to benefit, which are those with hyperuricemia and/ or a history of gout. Until further trials are done, we still would recommend urate-lowering drugs for this target population provided they show evidence of progression of their kidney disease. Careful attention to the potential toxicities of urate-lowering drugs is needed.

\section{Author's Contributions}

FP and FS equally contributed to the article and both are considered first authors. FP and FS wrote the paper with input from all authors.

\section{Conflict of Interest}

RJJ has equity with XORTX therapeutics that is developing novel xanthine oxidase inhibitors, and he has also consulted for Horizon Pharma. No other individuals have any conflicts of interest.

\section{References}

1. Bardin T, Richette P. Impact of comorbidities on gout and hyperuricaemia: an update on prevalence and treatment options. BMC Med. 2017;15(1):123.

2. Davis Junior NS. The cardio-vascular and renal relations and manifestations of gout. JAMA. 1897 Aug;29(6):261-2.

3. Johnson G. On the diseases of the kidney. London: John W Parker and Son; 1852.

4. Krishnan E, Akhras KS, Sharma H, Marynchenko M, Wu E, Tawk RH, et al. Serum urate and incidence of kidney disease among veterans with gout. J Rheumatol. 2013 May;40(7):116672.

5. Fuldeore MJ, Riedel AA, Zarotsky V, Pandya BJ, Dabbous O, Krishnan E. Chronic kidney disease in gout in a managed care setting. BMC Nephrol. 2011 Aug;12:36.

6. Johnson RJ, Nakagawa T, Jalal D, Sánchez-Lozada LG, Kang DH, Ritz E. Uric acid and chronic kidney disease: which is chasing which?. Nephrol Dial Transplant. 2013 Sep;28(9):2221-8.

7. Jordan DM, Choi HK, Verbanck M, Topless R, Won HH, Nadkarni G, et al. No causal effects of serum urate levels on the risk of chronic kidney disease: a Mendelian randomization study. PLoS Med. 2019 Jan;16(1):e1002725.

8. Álvarez-Lario B, Macarrón-Vicente J. Uric acid and evolution. Rheumatology (Oxford). 2010 Nov;49(11):2010-5.

9. Stewart DJ, Langlois V, Noone D. Hyperuricemia and hypertension: links and risks. Integr Blood Press Control. 2019 Dec;12:43-62.

10. Sanchez-Lozada LG, Rodriguez-Iturbe B, Kelley EE, Nakagawa T, Madero M, Feig DI, et al. Uric acid and hypertension: an update with recommendations. Am J Hypertens. 2020 Jul;33(7):583-94.

11. Xu X, Li C, Zhou P, Jiang T. Uric acid transporters hiding in the intestine. Pharm Biol. 2016 Dec;54(12):3151-5.

12. Guan H, Zheng Y, Zhou X, Xu Y, Fu C, Xiao J, et al. Efficacy of different urinary uric acid indicators in patients with chronic kidney disease. BMC Nephrol. 2020 Jul;21:290.
13. Fujita K, Yamada H, Iijima M, Ichida K. Electrochemical analysis of uric acid excretion to the intestinal lumen: effect of serum uric acid-lowering drugs and 5/6 nephrectomy on intestinal uric acid levels. PLoS One. 2019 Dec;14(12):e0226918.

14. Zhou F, Yu G, Wang G, Liu Y, Zhang L, Wang W, et al. Association of serum uric acid levels with the incident of kidney disease and rapid eGFR decline in Chinese individuals with eGFR $>60 \mathrm{~mL} / \mathrm{min} / 1.73 \mathrm{~m} 2$ and negative proteinuria. Clin Exp Nephrol. 2019 Jul;23(7):871-9.

15. Weiner DE, Tighiouart H, Elsayed EF, Griffith JL, Salem DN, Levey AS. Uric acid and incident kidney disease in the community. J Am Soc Nephrol. 2008 Jun;19(6):1204-11.

16. Tsai CW, Lin SY, Kuo CC, Huang CC. Serum uric acid and progression of kidney disease: a longitudinal analysis and minireview. PLoS One. 2017;12(1):e0170393.

17. Galvan AQ, Natali A, Baldi S, Frascerra S, Sanna G, Ciociaro $\mathrm{D}$, et al. Effect of insulin on uric acid excretion in humans. Am J Physiol. 1995 Jan;268(1 Pt 1):E1-5.

18. Gwinner W, Scheuer H, Haller H, Brandes RP, Groene HJ. Pivotal role of xanthine oxidase in the initiation of tubulointerstitial renal injury in rats with hyperlipidemia. Kidney Int. 2006 Feb;69(3):481-7.

19. Messerli FH, Frohlich ED, Dreslinski GR, Suarez DH, Aristimuno GG. Serum uric acid in essential hypertension: an indicator of renal vascular involvement. Ann Intern Med. 1980 Dec;93(6):817-21.

20. Macias-Kauffer LR, Villamil-Ramirez H, Leon-Mimila P, Jacobo-Albavera L, Posadas-Romero C, Posadas-Sanchez R, et al. Genetic contributors to serum uric acid levels in Mexicans and their effect on premature coronary artery disease. Int J Cardiol. 2019 Mar;279:168-73.

21. Salem CB, Slim R, Fathallah N, Hmouda H. Drug-induced hyperuricaemia and gout. Rheumatology (Oxford). 2017 May;56(5):679-88.

22. Ye M, Hu K, Jin J, Wu D, Hu P, He Q. The association between time-mean serum uric acid levels and the incidence of chronic kidney disease in the general population: a retrospective study. BMC Nephrol. 2018 Jul;19(1):190.

23. Srivastava A, Kaze AD, McMullan CJ, Isakova T, Waikar SS. Uric acid and the risks of kidney failure and death in individuals with CKD. Am J Kidney Dis. 2018 Mar;71(3):362-70.

24. Kim K, Go S, Son HE, Ryu JY, Lee H, Heo NJ, et al. Association between serum uric acid level and ESRD or death in a Korean population. J Korean Med Sci. 2020 Jul;35(28):e254.

25. Mok Y, Lee SJ, Kim MS, Cui W, Moon YM, Jee SH. Serum uric acid and chronic kidney disease: the Severance cohort study. Nephrol Dial Transplant. 2012 May;27(5):1831-5.

26. Sonoda H, Takase H, Dohi Y, Kimura G. Uric acid levels predict future development of chronic kidney disease. Am J Nephrol. 2011;33(4):352-7.

27. Iseki K. Significance of hyperuricemia among community-based screening participants. Contrib Nephrol. 2018;192:41-7.

28. Obermayr RP, Temml C, Knechtelsdorfer M, Gutjahr G, Kletzmayr J, Heiss S, et al. Predictors of new-onset decline in kidney function in a general middle-european population. Nephrol Dial Transplant. 2008 Apr;23(4):1265-73.

29. Obermayr RP, Temml C, Gutjahr G, Knechtelsdorfer M, Oberbauer R, Klauser-Braun R. Elevated uric acid increases the risk for kidney disease. J Am Soc Nephrol. 2008 Dec;19(12):2407-13.

30. Iseki K, Oshiro S, Tozawa M, Iseki C, Ikemiya Y, Takishita S. Significance of hyperuricemia on the early detection of renal failure in a cohort of screened subjects. Hypertens Res. 2001 Nov;24(6):691-7.

31. Chonchol M, Shlipak MG, Katz R, Sarnak MJ, Newman AB, Siscovick DS, et al. Relationship of uric acid with progression of kidney disease. Am J Kidney Dis. 2007 Aug;50(2):239-47.

32. Oh TR, Choi HS, Kim CS, Bae EH, Ma SK, Sung SA, et al. Hyperuricemia has increased the risk of progression of chronic kidney disease: propensity score matching analysis from the KNOW-CKD study. Sci Rep. 2019 Apr;9(1):6681. 
33. Madero M, Sarnak MJ, Wang X, Greene T, Beck GJ, Kusek $\mathrm{JW}$, et al. Uric acid and long-term outcomes in CKD. Am J Kidney Dis. 2009 May;53(5):796-803.

34. Kanda E, Muneyuki T, Kanno Y, Suwa K, Nakajima K. Uric acid level has a U-shaped association with loss of kidney function in healthy people: a prospective cohort study. PLoS One. 2015 Feb;10(2):e0118031.

35. Mori K, Furuhashi M, Tanaka M, Numata K, Hisasue T, Hanawa $\mathrm{N}$, et al. U-shaped relationship between serum uric acid level and decline in renal function during a 10-year period in female subjects: BOREAS-CKD2. Hypertens Res. 2020 Aug;44(1):107-16.

36. Testa A, Mallamaci F, Spoto B, Pisano A, Sanguedolce MC, Tripepi G, et al. Association of a polymorphism in a gene encoding a urate transporter with CKD progression. Clin J Am Soc Nephrol. 2014 Jun;9(6):1059-65.

37. Voruganti VS, Franceschini N, Haack K, Laston S, MacCluer JW, Umans JG, et al. Replication of the effect of SLC2A9 genetic variation on serum uric acid levels in American Indians. Eur J Hum Genet. 2014 Jul;22(7):938-43.

38. Rincon-Choles H, Jolly SE, Arrigain S, Konig V, Schold JD, Nakhoul G, et al. Impact of uric acid levels on kidney disease progression. Am J Nephrol. 2017;46(4):315-22.

39. Klauser AS, Halpern EJ, Strobl S, Gruber J, Feuchtner G, Bellmann-Weiler R, et al. Dual-energy computed tomography detection of cardiovascular monosodium urate deposits in patients with gout. JAMA Cardiol. 2019 Oct;4(10):1019-28.

40. Khanna P, Johnson RJ, Marder B, LaMoreaux B, Kumar A. Systemic urate deposition: an unrecognized complication of gout?. J Clin Med. 2020 Oct;9(10):3204.

41. Stack AG, Johnson ME, Blak B, Klein A, Carpenter L, Morlock $\mathrm{R}$, et al. Gout and the risk of advanced chronic kidney disease in the UK health system: a national cohort study. BMJ Open. 2019;9(8):e031550.

42. Badve SV, Brown F, Hawley CM, Johnson DW, Kanellis J, Rangan GK, et al. Challenges of conducting a trial of uricacid-lowering therapy in CKD. Nat Rev Nephrol. 2011 May;7(5):295-300.

43. Kang DH, Nakagawa T, Feng L, Watanabe S, Han L, Mazzali $\mathrm{M}$, et al. A role for uric acid in the progression of renal disease. J Am Soc Nephrol. 2002 Dec;13(12):2888-97.

44. Kang DH, Park SK, Lee IK, Johnson RJ. Uric acid-induced $\mathrm{C}$-reactive protein expression: implication on cell proliferation and nitric oxide production of human vascular cells. J Am Soc Nephrol. 2005 Dec;16(12):3553-62.

45. Gondouin B, Jourde-Chiche N, Sallee M, Dou L, Cerini C, Loundou A, et al. Plasma xanthine oxidase activity is predictive of cardiovascular disease in patients with chronic kidney disease, independently of uric acid levels. Nephron. 2015;131(3):167-74.

46. Kim YJ, Oh SH, Ahn JS, Yook JM, Kim CD, Park SH, et al. The crucial role of xanthine oxidase in CKD progression associated with hypercholesterolemia. Int J Mol Sci. 2020 Oct;21(20):7444

47. DeBosch BJ, Kluth O, Fujiwara H, Schurmann A, Moley K. Early-onset metabolic syndrome in mice lacking the intestinal uric acid transporter SLC2A9. Nat Commun. 2014 Aug;5:4642.

48. Piani F, Johnson RJ. Does gouty nephropathy exist, and is it more common than we think? Kidney Int. 2021 Jan;99(1):3133. doi: 10.1016/j.kint.2020.10.015. PMID: 33390238.

49. Bardin T, Nguyen QD, Tran KM, Le NH, Do MD, Richette $\mathrm{P}$, et al. A cross sectional study of 502 patients found a diffuse hyperechoic kidney medulla pattern in patients with severe gout. Kidney Int. 2021 Jan;99(1):218-26.

50. Sánchez-Lozada LG. The pathophysiology of uric acid on renal diseases. Contrib Nephrol. 2018;192:17-24.

51. Sanchez-Lozada LG, Soto V, Tapia E, Avila-Casado C, Sautin YY, Nakagawa T, et al. Role of oxidative stress in the renal abnormalities induced by experimental hyperuricemia. Am J Physiol Renal Physiol. 2008 Oct;295(4):F1134-41.
52. Mazzali M, Hughes J, Kim YG, Jefferson JA, Kang DH, Gordon $\mathrm{KL}$, et al. Elevated uric acid increases blood pressure in the rat by a novel crystal-independent mechanism. Hypertension. 2001 Nov;38(5):1101-6.

53. Ryu ES, Kim MJ, Shin HS, Jang YH, Choi HS, Jo I, et al. Uric acid-induced phenotypic transition of renal tubular cells as a novel mechanism of chronic kidney disease. Am J Physiol Renal Physiol. 2013 Mar;304(5):F471-80.

54. Verzola D, Ratto E, Villaggio B, Parodi EL, Pontremoli R, Garibotto $G$, et al. Uric acid promotes apoptosis in human proximal tubule cells by oxidative stress and the activation of NADPH oxidase NOX 4. PLoS One. 2014 Dec;9(12):e115210.

55. Zhou Y, Fang L, Jiang L, Wen P, Cao H, He W, et al. Uric acid induces renal inflammation via activating tubular NF-kappaB signaling pathway. PLoS One. 2012;7(6):e39738.

56. Sanchez-Lozada LG, Tapia E, Santamaría J, Avila-Casado C, Soto V, Nepomuceno T, et al. Mild hyperuricemia induces vasoconstriction and maintains glomerular hypertension in normal and remnant kidney rats. Kidney Int. 2005 Jan;67(1):237-47.

57. Stavric B, Nera EA, Johnson WJ, Salem FA. Uric acid kidney stones induced in rats by oxonic acid, a uricase inhibitor. Invest Urol. 1973 Jul;11(1):3-8.

58. Sato Y, Feig DI, Stack AG, Kang DH, Lanaspa MA, Ejaz AA, et al. The case for uric acid-lowering treatment in patients with hyperuricaemia and CKD. Nat Rev Nephrol. 2019 Dec;15(12):767-75.

59. Doria A, Galecki AT, Spino C, Pop-Busui R, Cherney DZ, Lingvay I, et al. Serum urate lowering with allopurinol and kidney function in type 1 diabetes. N Engl J Med. 2020 Jun;382(26):2493-503.

60. Badve SV, Pascoe EM, Tiku A, Boudville N, Brown FG, Cass A, et al. Effects of allopurinol on the progression of chronic kidney disease. N Engl J Med. 2020 Jun;382(26):2504-13.

61. Jung JW, Song WJ, Kim YS, Joo KW, Lee KW, Kim SH, et al. HLA-B58 can help the clinical decision on starting allopurinol in patients with chronic renal insufficiency. Nephrol Dial Transplant. 2011 Nov;26(11):3567-72.

62. White WB, Saag KG, Becker MA, Borer JS, Gorelick PB, Whelton A, et al. Cardiovascular safety of febuxostat or allopurinol in patients with gout. N Engl J Med. 2018 Mar;378(13):1200-10.

63. Mackenzie IS, Ford I, Nuki G, Hallas J, Hawkey CJ, Webster J, et al. Long-term cardiovascular safety of febuxostat compared with allopurinol in patients with gout (FAST): a multicentre, prospective, randomised, open-label, non-inferiority trial. Lancet. 2020 Nov;396(10264):1745-57.

64. Johnson TA, Kamatani N, Kuwabara M. Xanthine oxidase inhibitor withdrawal syndrome? comment on the article by Choi et al. Arthritis Rheumatol. 2019 Nov;71(11):1966-7.

65. Talaat KM, El-Sheikh AR. The effect of mild hyperuricemia on urinary transforming growth factor beta and the progression of chronic kidney disease. Am J Nephrol. 2007;27(5):435-40.

66. Feig DI, Soletsky B, Johnson RJ. Effect of allopurinol on blood pressure of adolescents with newly diagnosed essential hypertension: a randomized trial. JAMA. 2008 Aug;300(8):924-32.

67. Siu YP, Leung KT, Tong MK, Kwan TH. Use of allopurinol in slowing the progression of renal disease through its ability to lower serum uric acid level. Am J Kidney Dis. 2006 Jan;47(1):51-9.

68. Goicoechea M, Vinuesa SG, Verdalles U, Ruiz-Caro C, Ampuero $\mathrm{J}$, Rincón A, et al. Effect of allopurinol in chronic kidney disease progression and cardiovascular risk. Clin J Am Soc Nephrol. 2010 Aug;5(8):1388-93.

69. Hosoya T, Ohno I, Nomura S, Hisatome I, Uchida S, Fujimori $S$, et al. Effects of topiroxostat on the serum urate levels and urinary albumin excretion in hyperuricemic stage 3 chronic kidney disease patients with or without gout. Clin Exp Nephrol. 2014 Dec;18(6):876-84.

70. Sircar D, Chatterjee S, Waikhom R, Golay V, Raychaudhury A, Chatterjee S, et al. Efficacy of febuxostat for slowing the GFR decline in patients with CKD and asymptomatic hyperuricemia: a 
6-month, double-blind, randomized, placebo-controlled trial. Am J Kidney Dis. 2015 Dec;66(6):945-50.

71. Liu X, Zhai T, Ma R, Luo C, Wang H, Liu L. Effects of uric acid-lowering therapy on the progression of chronic kidney disease: a systematic review and meta-analysis. Ren Fail. 2018 Nov;40(1):289-97.

72. Kimura K, Hosoya T, Uchida S, Inaba M, Makino H, Maruyama $\mathrm{S}$, et al. Febuxostat therapy for patients with stage $3 \mathrm{ckd}$ and asymptomatic hyperuricemia: a randomized trial. Am J Kidney Dis. 2018 Dec;72(6):798-810.

73. Lee JW, Lee KH. Comparison of renoprotective effects of febuxostat and allopurinol in hyperuricemic patients with chronic kidney disease. Int Urol Nephrol. 2019 Mar;51(3):467-73.

74. Hsu YO, Wu IW, Chang SH, Lee CC, Tsai CY, Lin CY, et al. Comparative Renoprotective Effect of Febuxostat and Allopurinol in Predialysis Stage 5 Chronic Kidney Disease Patients: A Nationwide Database Analysis. Clin Pharmacol Ther. 2020;107(5):1159-69.
75. Sezai A, Unosawa S, Taoka M, Osaka S, Sekino H, Tanaka M. Changeover Trial of Febuxostat and Topiroxostat for Hyperuricemia with Cardiovascular Disease: Sub-Analysis for Chronic Kidney Disease (TROFEO CKD Trial). Ann Thorac Cardiovasc Surg. 2020;26(4):202-8.

76. Hsu YO, Wu IW, Chang SH, Lee CC, Tsai CY, Lin CY, et al. Comparative renoprotective effect of febuxostat and allopurinol in predialysis stage 5 chronic kidney disease patients: a nationwide database analysis. Clin Pharmacol Ther. 2020 May;107(5):1159-69.

77. Sezai A, Unosawa S, Taoka M, Osaka S, Sekino H, Tanaka M. Changeover trial of febuxostat and topiroxostat for hyperuricemia with cardiovascular disease: sub-analysis for chronic kidney disease (TROFEO CKD Trial). Ann Thorac Cardiovasc Surg. 2020 Aug;26(4):202-8. 